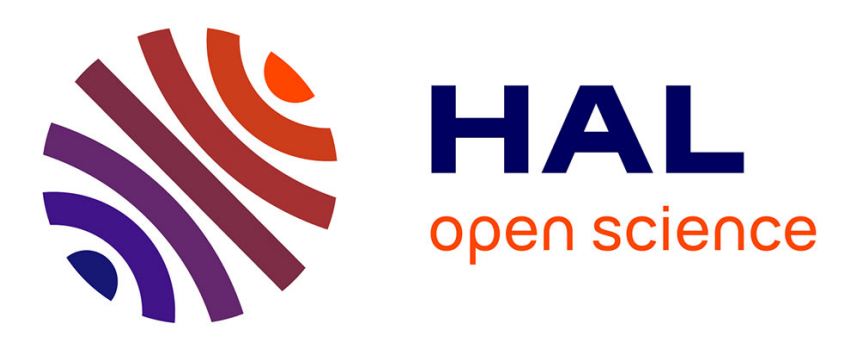

\title{
Spin-Crossover and Field-Induced Single-Molecule Magnet Behaviour in Metal(II)-Dipyrazolylpyridine Complexes
}

Haiet Douib, Louis Cornet, Jessica Flores Gonzalez, Elzbieta Trzop, Vincent Dorcet, Abdelkrim Gouasmia, Lahcène Ouahab, Olivier Cador, Fabrice Pointillart

\section{To cite this version:}

Haiet Douib, Louis Cornet, Jessica Flores Gonzalez, Elzbieta Trzop, Vincent Dorcet, et al.. SpinCrossover and Field-Induced Single-Molecule Magnet Behaviour in Metal(II)-Dipyrazolylpyridine Complexes. European Journal of Inorganic Chemistry, 2018, 2018 (40), pp.4452-4457. 10.1002/ejic.201800819 . hal-01935237

\section{HAL Id: hal-01935237 \\ https://hal-univ-rennes1.archives-ouvertes.fr/hal-01935237}

Submitted on 4 Dec 2018

HAL is a multi-disciplinary open access archive for the deposit and dissemination of scientific research documents, whether they are published or not. The documents may come from teaching and research institutions in France or abroad, or from public or private research centers.
L'archive ouverte pluridisciplinaire HAL, est destinée au dépôt et à la diffusion de documents scientifiques de niveau recherche, publiés ou non, émanant des établissements d'enseignement et de recherche français ou étrangers, des laboratoires publics ou privés. 


\title{
Spin Crossover and Field-Induced Single-Molecule Magnet Behaviour in Metal(II)-Dipyrazolylpyridine Complexes
}

\author{
Haiet Douib, ${ }^{\text {a,b }}$ Louis Cornet, ${ }^{a}$ Jessica Flores Gonzalez, ${ }^{a}$ Elzbieta Trzop, ${ }^{c}$ Vincent Dorcet, ${ }^{\text {a }}$ Abdelkrim \\ Gouasmia, ${ }^{\mathrm{b}}$ Lahcène Ouahab, ${ }^{\mathrm{a}}$ Olivier Cador, ${ }^{\text {a }}$ Fabrice Pointillart, ${ }^{\text {*a }}$
}

\begin{abstract}
The reaction between the 2,6-di(pyrazol-1-yl)-4(bromomethyl)pyridine (L) ligand and divalent transition metal salts led to the formation of three mononuclear complexes of formula $\left[\mathrm{M}(\mathrm{L})_{2}\right]\left(\mathrm{BF}_{4}\right)_{2} \cdot \mathrm{xMeNO}_{2}\left(\mathrm{M}=\mathrm{Fe}^{\prime \prime}\left(\mathbf{1} \cdot \mathrm{xMeNO}_{2}\right), \mathrm{x}=0\right.$ and $4, \mathrm{M}=\mathrm{Co} " \mathrm{l}, \mathrm{x}$ $=2\left(\mathbf{2} \cdot \mathbf{2} \mathrm{MeNO}_{2}\right)$ and). Static magnetic measurements highlighted thermal spin crossover at high temperature (320-340 K) for the two Fe" solvatomorphs nevertheless both the solvation degree and crystal packing had drastic influence on the shape and width of the hysteresis loop. Thus the 1 displayed abrupt and straight $(6 \mathrm{~K})$ hysteresis loop while for $1.4 \mathrm{MeNO}_{2}$ the thermal spin transition could be described as a six-step gradual transition with the widest magnetic bistability range $(35 \mathrm{~K})$ for this kind of complexes. Irradiation at $530 \mathrm{~nm}$ of $\mathbf{1 . 4 \mathrm { MeNO } _ { 2 }}$ provoked an efficient LIESST effect at low temperature ( $T_{\text {LIESST }}=55$ $\mathrm{K})$. Finally dynamic magnetic measurements of $\mathbf{2 \cdot 2} \mathrm{MeNO}_{2}$ shown a field-induced mononuclear Single-Molecule Magnet behavior with $\Delta=$ $14.6(4) \mathrm{cm}^{-1}$ and $\tau_{0}=6.28(8) \times 10^{-7} \mathrm{~s}$.
\end{abstract}

\section{Introduction}

Molecular magnetic bistability is intensively studied by both chemist and physicist communities of the molecular magnetism due to the wide potential applications such as high-density memory capacities. ${ }^{[1]}$ Such magnetic behaviour could be observed under different stimuli. Thus under magnetic field, Single-Molecule Magnets $(\mathrm{SMMs})^{[2]}$ is targeted while Spin CrossOver $(\mathrm{SCO})^{[3]}$ is the intended behaviour under temperature variation or light irradiation among other stimuli (pressure...).

The SCO behaviour is a well-known phenomenon since the 1930s. ${ }^{[4]}$ By restricting the external stimuli to the temperature and light irradiation, the magnetic bistability can be thermodynamically (thermal SCO) and kinetically (photo-induced SCO called lightinduced excited spin state trapping, LIESST ${ }^{[5]}$ reached. The magnetic bistability is driven mainly by the cooperativity induced

[a] H.D., L.C., J.F.G., V.D., L.O., O.C. F.P.

Univ Rennes, CNRS, ISCR (Institut des Sciences Chimiques de Rennes) - UMR 6226, F-35000 Rennes, France.

fabrice.pointillart@univ-rennes1.fr

[b] H.D., A.G

Laboratoire des Matériaux Organiques et Hétérochimie (LMOH), Département de sciences de la matière, Université de Tébessa, Rue de Constantine 12002, Tébessa, Algérie.

[c] E.T.

Institut de Physique de Rennes, Université de Rennes 1, UMR UR1CNRS 6251, Rennes, France.

Supporting information for this article is given via a link at the end of the document. by intermolecular interactions in the crystal lattice. All the metallic ion with the $d^{4}-d^{7}$ electronic configuration are potential candidates to SCO behaviour nevertheless the most popular metal ion is unambiguously the Fe" because it allows the largest variation of the spin value involving paramagnetic and diamagnetic states (S $=2 \rightarrow S=0$ ). Obviously, the choice of the nature of the ligand is crucial to impose an adequate crystal ligand field to the Fell. Thus the bpp- $R$ ligand (where the bpp- $R$ is a 2,6-di(pyrazol-1$\mathrm{yl}$ )pyridine derivative is one of the most used ligand to be associated with the $\mathrm{Fe}^{\mathrm{Il}}$ ion leading to $\left[\mathrm{Fe}(\mathrm{bpp}-\mathrm{R})_{2}\right]^{2+}$ series of complexes. ${ }^{[6]}$ The reason of the high popularity of such series of complexes is due to its ability to show thermal (near room temperature) and photo-induced spin crossover as well as the chemical-dependence of the spin transition. Therefore the observation or not of the spin transition and the temperature at which the spin transition could occur strongly depend of the substituent of the bpp moiety, ${ }^{[7]}$ the nature of the solvent of the crystal lattice ${ }^{[8]}$ the nature of the anions ${ }^{[9]}$ and the Jahn-Teller distortion ${ }^{[10]}$

Since the discovery of magnetic bistability at low temperature for a mononuclear lanthanide complex, ${ }^{[11]}$ the interest for such simple systems were growing rapidly. Thus chemist community started to study mononuclear complexes of $3 d$ ions to design SMMs. These systems mainly involved high-

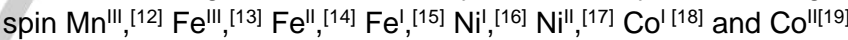
ions. The last Co"-based SMMs highlighted a large number of coordination for the metal ion ranging from two to eight ${ }^{[20]}$ nevertheless the slow magnetic relaxation is usually observed under applied DC field to cancel the quantum tunnelling relaxation except for few examples of organometallic complexes ${ }^{[21]}$. Slow magnetic relaxation of the magnetization was rarely observed in system combining one 2,6-di(pyrazol-1-yl)pyridine derivative (bpp-R) and $\mathrm{Co}^{11[22]}$ and the probe of magnetic properties for $\left[\mathrm{Co}(\mathrm{bpp}-\mathrm{R})_{2}\right]^{2+}$ complexes is very scarce in literature ${ }^{[23]}$.

The aim of our final project is to combine both SMM and SCO behaviour in a unique system by functionalizing the 2-(4,5(4,5-bis(propylthio)-tetrathiafulvalenyl)-1H-benzimidazol-2-yl)pyridine molecular skeleton by alkylation of the amine with a bromo-methyl-derivative such as the 2,6-di(pyrazol-1-yl)-4(bromomethyl)pyridine (L). ${ }^{[24]}$ A new approach is now to prepare the metal complexes involving the $\mathbf{L}$ ligand which could be therefore used as precursors to perform metallo-alkylation of our molecular skeleton. In the following lines, we reported the X-ray structures and the (photo)magnetic properties of two of such potential metallo-precursors of formula $\left[\mathrm{M}(\mathrm{L})_{2}\right]\left(\mathrm{BF}_{4}\right)_{2} \cdot \mathrm{xMeNO}_{2}(\mathrm{M}$ $=\mathrm{Co}^{\mathrm{II}}, \mathrm{x}=2$ and $\mathrm{M}=\mathrm{Fe}(\mathrm{II}), \mathrm{x}=0$ and 4$)$. 


\section{Results and Discussion}

\section{Crystal structure}

Slow diffusion of $\mathrm{Et}_{2} \mathrm{O}$ vapor into $\mathrm{MeNO}_{2}$ solution of $\left[\mathrm{Fe}(\mathbf{L})_{2}\right]\left(\mathrm{BF}_{4}\right)_{2}$ yields mixtures of brown plate $\left[\mathrm{Fe}(\mathbf{L})_{2}\right]\left(\mathrm{BF}_{4}\right)_{2}$ and prism $\left[\mathrm{Fe}(\mathrm{L})_{2}\right]\left(\mathrm{BF}_{4}\right)_{2} \cdot 4 \mathrm{MeNO}_{2}$ single crystals with variable ratio.

[Fe(L)2] $\left(\mathrm{BF}_{4}\right)_{2}(\mathbf{1})$. Compound 1 crystallizes in the orthorhombic space group Pbcn ( $\left.\mathrm{N}^{\circ} 60\right)$ (Table 1 ). The ORTEP drawing of $\mathbf{1}$ is shown in Figure 1a. The asymmetric unit is composed of one half molecule of $\left[\mathrm{Fe}(\mathbf{L})_{2}\right]^{2+}$ and one $\mathrm{BF}_{4}-$ anion.

(a)

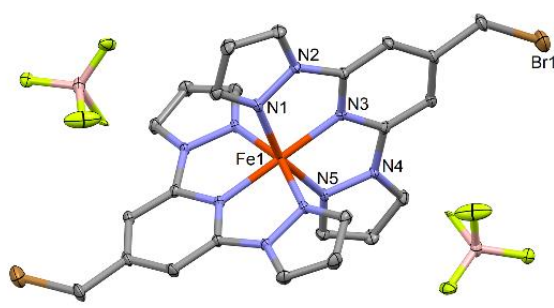

(b)

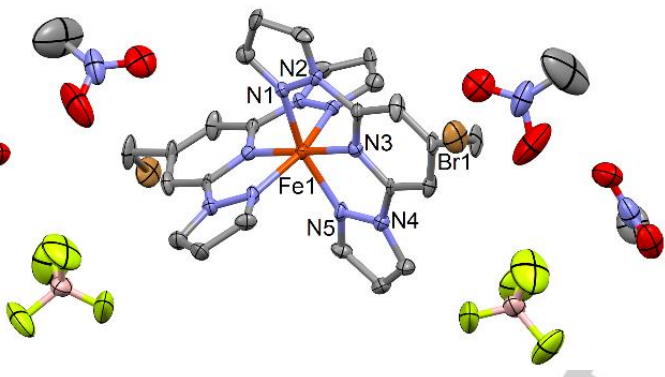

Figure 1. Ortep View of the structures of $\mathrm{Fe}$ (a) and $\mathbf{F e} \cdot 4 \mathrm{MeNO}_{2}$ (b). Atomic displacement ellipsoids are drawn at the $30 \%$ probability level. Hydrogen atoms are omitted for clarity.

The Fell centre is coordinated to two trischelating ligands conferring a $\mathrm{N} 6$ surrounding. The average $\mathrm{Fe}-\mathrm{N}$ bond lengths is equal to $1.947(3) \AA$ with a slight difference between the $\mathrm{Fe}-\mathrm{N}_{(\mathrm{py})}$ distances $(1.888(3) \AA)$ which are shorter than the $\mathrm{Fe}-\mathrm{N}_{(\mathrm{pz})}$ distances $(1.969(3) \AA)$ due to the difference of Lewis basis strength between a pyridine and a pyrazole unit. Such bond lengths strongly suggest that the $\mathrm{Fe}^{\| l}$ ion is in its low-spin state (S $=0$ ) at $200 \mathrm{~K}$ in the Fe compound. The characteristic $\mathrm{N}_{(\mathrm{pz})}-\mathrm{Fe}-\mathrm{N}(\mathrm{pz})$ and $\mathrm{N}_{(\mathrm{py})}-\mathrm{Fe}-\mathrm{N}_{(\mathrm{py})}$ angles have been measured to $160.3(1)^{\circ}$ and $174.6(1)^{\circ}$ respectively. The two coordinated $\mathbf{L}$ ligands are perpendicular. The $\mathrm{CH}_{2} \mathrm{Br}$ substituent is localized in the plan formed by the bpp fragment (Figure 2b).

The crystal packing of $\mathbf{1}$ highlights the formation of stack of molecules into a pseudo "terpyridine embrace" lattice i.e. a packing which is dominated by face-to-face $\pi-\pi$ interactions and edge-to-face $\mathrm{C}-\mathrm{H} \cdots \pi$ contacts between the pyrazole moieties of neighbouring complexes. ${ }^{[25]}$ The regular "terpyridine embrace" lattice form a stacked layers of molecules[26] while for the 1 compound the $\pi-\pi$ stacking takes only place along one direction
(Figure 2a). Interestingly, in a perpendicular direction (along the a axis) to the pseudo "terpyridine embrace" lattice, $\mathrm{Br} \cdots \mathrm{Br}$ short contacts $(3.617 \AA)$ are identified and could have consequences in the magnetic behavior. ${ }^{[7]}$

(a)
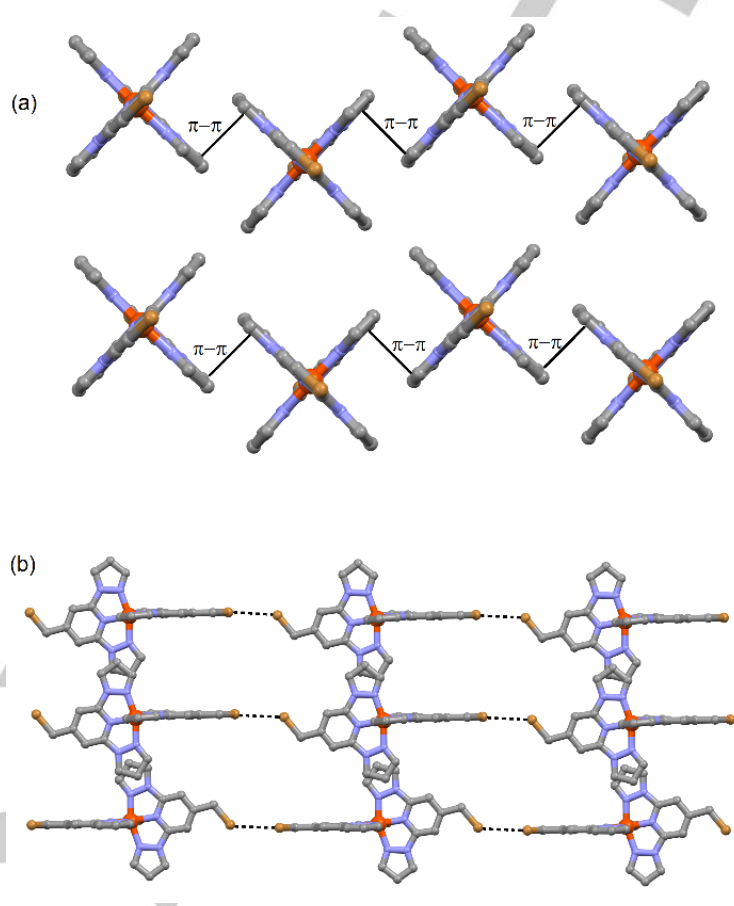

Figure 2. Crystal packing of 1 highlighting the pseudo "terpyridine embrace" (a) and the $\mathrm{Br} \cdots \mathrm{Br}$ short contacts (b).

Table 1. X-ray crystallographic data for the complexes $1,1.4 \mathrm{MeNO}_{2}$ and 2.2 $\mathrm{MeNO}_{2}$.

\begin{tabular}{|c|c|c|c|}
\hline Compounds & $\begin{array}{c}{\left[\mathrm{Fe}(\mathrm{L})_{2}\right]\left(\mathrm{BF}_{4}\right)_{2}} \\
(\mathbf{1})\end{array}$ & $\begin{array}{c}{\left[\mathrm{Fe}(\mathrm{L})_{2}\right]\left(\mathrm{BF}_{4}\right)_{2} \cdot 4 \mathrm{MeNO}_{2}} \\
\left(1.4 \mathrm{MeNO}_{2}\right)\end{array}$ & $\begin{array}{c}{\left[\mathrm{Co}(\mathrm{L})_{2}\right]\left(\mathrm{BF}_{4}\right)_{2} \cdot 2 \mathrm{MeNO}_{2}} \\
\left(\mathbf{2} \cdot 2 \mathrm{MeNO}_{2}\right)\end{array}$ \\
\hline $\begin{array}{l}\text { Formula } \\
\mathrm{M} / \mathrm{g} \mathrm{mol}^{-1}\end{array}$ & $\begin{array}{l}\mathrm{C}_{24} \mathrm{H}_{20} \mathrm{~F}_{8} \mathrm{FeN}_{10} \mathrm{Br}_{2} \mathrm{~B}_{2} \\
837.77\end{array}$ & $\begin{array}{l}\mathrm{C}_{28} \mathrm{H}_{32} \mathrm{~F}_{8} \mathrm{FeN}_{14} \mathrm{O}_{8} \mathrm{Br}_{2} \mathrm{~B}_{2} \\
1081.96\end{array}$ & $\begin{array}{l}\mathrm{C}_{26} \mathrm{H}_{26} \mathrm{~F}_{8} \mathrm{CoN}_{12} \mathrm{O}_{4} \mathrm{Br}_{2} \mathrm{~B}_{2} \\
962.96\end{array}$ \\
\hline Crystal system & Orthorhombic & Orthorhombic & Triclinic \\
\hline Space group & Pbcn (N60) & Iba2 (N45) & $\mathrm{P}-1\left(\mathrm{~N}^{\circ} 2\right)$ \\
\hline Cell parameters & $\begin{array}{l}\mathrm{a}=18.0328(3) \AA \\
\mathrm{b}=10.2933(2) \AA \\
\mathrm{c}=15.7133(3) \AA\end{array}$ & $\begin{array}{l}\mathrm{a}=15.3072(18) \AA \\
\mathrm{b}=16.2477(19) \AA \\
\mathrm{c}=16.3779(17) \AA\end{array}$ & $\begin{array}{l}\mathrm{a}=8.0294(6) \AA \\
\mathrm{b}=8.8561(7) \AA \\
\mathrm{c}=25.623(2) \AA \\
\mathrm{a}=90.508(3) \\
\beta=96.528(2) \\
\mathrm{Y}=97.459(2)\end{array}$ \\
\hline Volume $/ \hat{A}^{3}$ & $2916.7(9)$ & $4073.3(8)$ & $1794.4(2)$ \\
\hline Z & 4 & 4 & 2 \\
\hline $\mathrm{T} / \mathrm{K}$ & $200(2)$ & $150(2)$ & $150(2)$ \\
\hline $2 \theta$ range $^{\circ}{ }^{\circ}$ & $6.54 \leq 2 \theta \leq 53.99$ & $4.99 \leq 2 \theta \leq 58.68$ & $4.64 \leq 2 \theta \leq 55.01$ \\
\hline$\rho_{\text {calc }} /$ g.cm ${ }^{-3}$ & 1.908 & 1.764 & 1.782 \\
\hline$\mu / \mathrm{mm}^{-1}$ & 3.346 & 2.435 & 2.799 \\
\hline $\begin{array}{l}\text { Number of } \\
\text { reflections }\end{array}$ & 47488 & 40076 & 39301 \\
\hline $\begin{array}{l}\text { Independent } \\
\text { reflections }\end{array}$ & 3175 & 4618 & 8250 \\
\hline$R_{\text {int }}$ & 0.0282 & 0.0639 & 0.0584 \\
\hline $\mathrm{Fo}^{2}>2 \sigma(\mathrm{Fo})^{2}$ & 2839 & 4395 & 6763 \\
\hline $\begin{array}{l}\text { Number of } \\
\text { variables }\end{array}$ & 250 & 286 & 496 \\
\hline $\mathrm{R}_{1}, \mathrm{wR} \mathrm{R}_{2}$ & $0.0572,0.1898$ & $0.0350,0.0879$ & $0.0450,0.0934$ \\
\hline
\end{tabular}

$\left[\mathrm{Fe}(\mathrm{L})_{2}\right]\left(\mathrm{BF}_{4}\right)_{2} \cdot 4 \mathrm{MeNO}_{2} \quad\left(1 \cdot 4 \mathrm{MeNO}_{2}\right) .1 \cdot 4 \mathrm{MeNO} 2$ crystallizes in the orthorhombic space group lba2 ( $\left.{ }^{\circ} 45\right)$ (Table 1). The ORTEP drawing of $1.4 \mathrm{MeNO}_{2}$ is shown in Figure $1 \mathrm{~b}$. The asymmetric unit 
is composed of one half molecule of $\left[\mathrm{Fe}(\mathrm{L})_{2}\right]^{2+}$, one $\mathrm{BF}_{4}{ }^{-}$anion and two nitromethane molecules of crystallization. Both solvated $1.4 \mathrm{MeNO}_{2}$ and unsolvated 1 complexes are very similar. No significant difference of $\mathrm{Fe}-\mathrm{N}$ distances are identified between the two complexes $\left(\mathrm{Fe}-\mathrm{N}_{(\mathrm{py})}=1.895(3) \AA\right.$ and $\left.\mathrm{Fe}-\mathrm{N}_{(\mathrm{pz})}=1.942(3) \AA\right)$ and thus the $\mathrm{Fe}^{\text {ll }}$ centre is in its LS state at the temperature of the $\mathrm{X}$-ray structure resolution $(150 \mathrm{~K})$. The characteristic $\mathrm{N}_{(\mathrm{pz})}-\mathrm{Fe}-\mathrm{N}_{(\mathrm{pz})}$ and $\mathrm{N}_{(\mathrm{py})}-\mathrm{Fe}-\mathrm{N}_{(\mathrm{py})}$ angles have been measured to $161.3(1)^{\circ}$ and $179.6(1)^{\circ}$ respectively. The two coordinated $\mathbf{L}$ ligands formed an angle of $79.2(4)^{\circ}$. Significant local structural changes are identified compared to $\mathbf{1}$ which should induce significance variation in the crystal filed around the $\mathrm{Fe}$ ll ion. The $\mathrm{CH}_{2} \mathrm{Br}$ substituent is localised at $58.7^{\circ}$ of the plan formed by the bpp fragment which is one more structural difference compared to 1 .

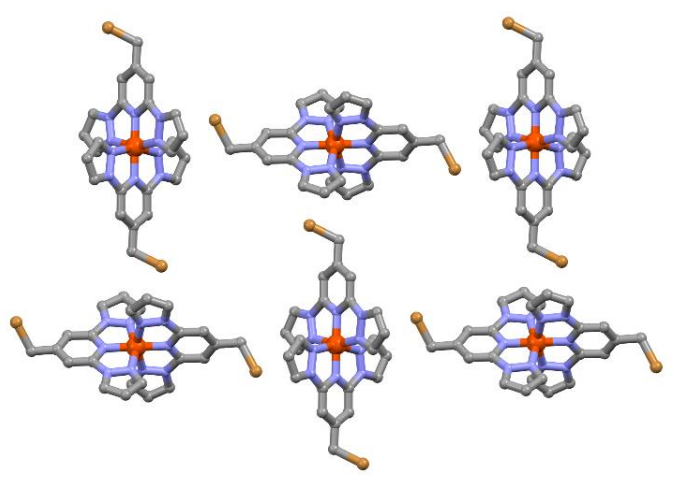

Figure 3. Crystal packing for $1.4 \mathrm{MeNO}_{2}$.

The presence of nitromethane molecules in the crystal induced drastic change for the stack of the complexes since the $\pi \cdots \pi$ and $\mathrm{Br} \cdots \mathrm{Br}$ contacts are lost (Figure 3 ). The crystal packing highlighted perpendicular arrangement of the complexes. The section on the magnetic properties will show the consequence of the structural changes between the two complexes.

$\left[\mathrm{Co}(\mathrm{L})_{2}\right]\left(\mathrm{BF}_{4}\right)_{2} \cdot 2 \mathrm{MeNO}_{2}\left(2 \cdot 2 \mathrm{MeNO}_{2}\right)$

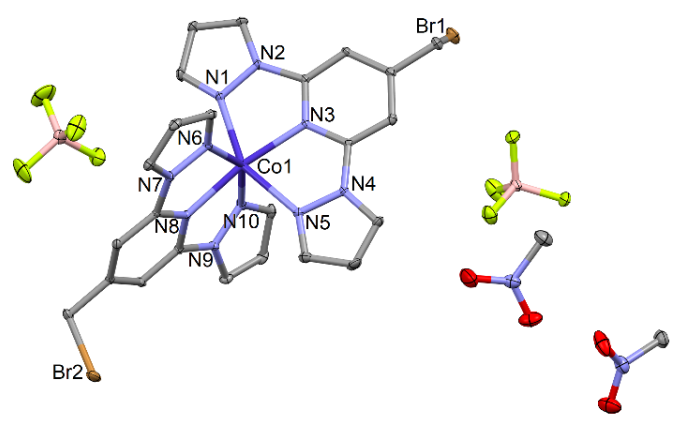

Figure 4. Ortep View of the structure of $\mathbf{C o} \cdot \mathbf{2} \mathbf{M e N O}_{2}$. Atomic displacement ellipsoids are drawn at the $30 \%$ probability level. Hydrogen atoms are omitted for clarity.
Co.2 $\mathrm{MeNO}_{2}$ crystallizes in the triclinic space group $\mathrm{P}-1$ ( $\left.\mathrm{N}^{\circ} 2\right)$ (Table 1). The ORTEP view of $\mathbf{C o} \cdot \mathbf{2} \mathbf{M e N O}_{2}$ is shown in Figure 4. The asymmetric unit is composed of one molecule of $\left[\mathrm{Co}(\mathbf{L})_{2}\right] 2+$, two $\mathrm{BF}_{4}$ anion and two nitromethane molecules of crystallization. The characteristic compressed octahedral polyhedron is observed with Co- $\mathrm{N}_{(\mathrm{py})}=2.066 \AA$ and $\mathrm{Co}-\mathrm{N}_{(\mathrm{pz})}=2.143$ (3) $\AA$. Such $\mathrm{Co}-\mathrm{N}$ bond lengths designated a HS state $\mathrm{Co}^{\text {"l }}$ centre. The longer Co-N distances compared to the Fe-N distances lead to smaller $\mathrm{N}_{(\mathrm{pz})}-\mathrm{Co}-\mathrm{N}_{(\mathrm{pz})} \quad\left(149.5(1)^{\circ}\right.$ and $\left.150.8(1)^{\circ}\right)$ and $\mathrm{N}_{(\mathrm{py})}-\mathrm{Co}-\mathrm{N}_{(\mathrm{py})}$ $\left(170.2(1)^{\circ}\right)$ angles compared to its $\mathrm{Fe}^{\prime l}$ analogue. The two $\mathrm{L}$ ligands are close to be perpendicular with an angle of $83.0(1)^{\circ}$. Nevertheless while one $L$ is planar (as observed for the two $\mathrm{Fe}^{\prime \prime}$ solvatomorphs) the second one is not. In fact the two plans formed by the pyridine ring and one of the pyrazole unit display an angle of $16.0(1)^{\circ}$.

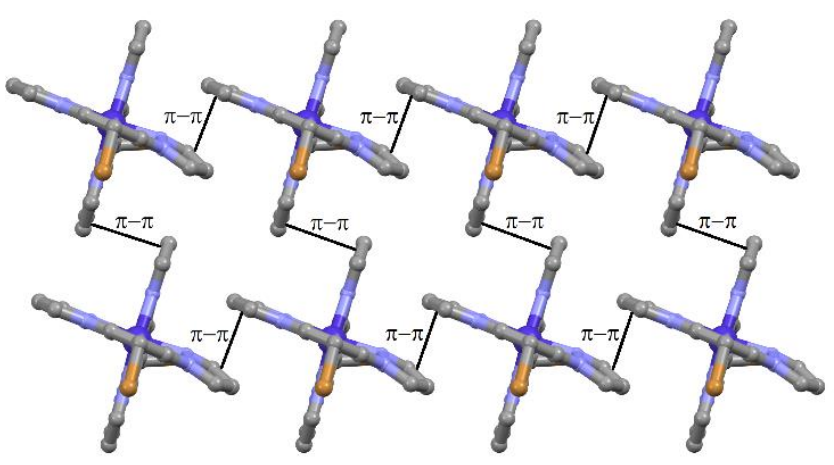

Figure 5. Crystal packing for $2 \cdot 2 \mathrm{MeNO}_{2}$.

The Figure 5 highlighted a regular "terpyridine embrace" crystal packing for $\mathbf{2 . 2} \mathrm{MeNO}_{2}$ with $\mathrm{CH}_{2} \mathrm{Br}$ groups localized at $68.8^{\circ}$ and $81.4^{\circ}$ of the plane formed by the bpp fragments.

\section{Magnetic measurements}

$\left[\mathrm{Fe}(\mathrm{L})_{2}\right]\left(\mathrm{BF}_{4}\right)_{2}$ (1). Magnetic susceptibility measurements of 1 shows an abrupt $\mathrm{HS}\left(\mathrm{S}=2, \chi_{\mathrm{M}} \mathrm{T}=3.95 \mathrm{~cm}^{3} \mathrm{~K} \mathrm{~mol}^{-1}\right)$ to $\mathrm{LS}(\mathrm{S}=0)$ transition centred around $324 \mathrm{~K}$ with a straight thermal hysteresis $(4 \mathrm{~K})$. On cooling, the transition occurs at $\mathrm{T}_{\mathrm{C}}=326 \mathrm{~K}$ while increasing the temperature the transition occurs at $322 \mathrm{~K}$. Such abrupt transition with a straight magnetic bistability are associated with the "terpyridine embrace" crystal packing form and an octahedral coordination sphere characterized by the two angles $\phi$ $=180^{\circ}$ and $\theta=90^{\circ}[9]$ in the HS state of 1 complex. The spin transition temperature is higher than the room temperature which is surprising since the analogue complex with two hydrogen atoms instead of the bromide atoms highlighted a spin transition centred at $207 \mathrm{~K}^{\left[{ }^{[9]}\right.}$ Such substitution and the resulting $\mathrm{Br} \cdots \mathrm{Br}$ short contacts clearly stabilize the LS state of $\mathbf{1}$.

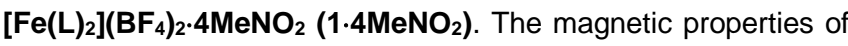
the solvated derivative showed a more progressive spin transition around $340 \mathrm{~K}$ with a wider thermal hysteresis ( $35 \mathrm{~K}$ ) compared to the unsolvated derivative (Figure 6). Based on the previous 
Halcrow's works, the difference of hysteresis width and temperature of transition could be attributed to both solvation ${ }^{[8]}$ and a moderate Jahn-Teller distortion of the HS state ${ }^{[10]}$ for 1.4MeNO $\mathrm{M}_{2}$. Unfortunately the complete thermal spin crossover is localized at to high temperature ( $\mathrm{T}>400 \mathrm{~K}$ ) to perform data collection and refinement of the $\mathrm{HS}$ state structure for $1.4 \mathrm{MeNO}_{2}$. It is worth to notice that the $1.4 \mathrm{MeNO}_{2}$ compound presents the widest hysteresis loop measured for a $\left[\mathrm{Fe}(\mathrm{bpp}-\mathrm{R})_{2}\right]^{2+}$ derivatives since the previous record was measured at $18 \mathrm{~K}$ for the methylsubstituted analogue. ${ }^{[9]}$ The form of the crystal packing imposed by the orientation of the bromide substitutions and the presence of nitromethane molecules of crystallization might be the origin of a such large hysteresis loop. In addition, one can observe that the $\chi_{M} T$ product decreased in cooling mode in a six-step manner centred at $265,280,295,315,335$ and $355 \mathrm{~K}$ (see the derivative of the data plot in Figure $\mathrm{S} 1$ ). The hysteresis loop remains open after several warming cycle and it cannot be attributed to desolvation or irreversible crystallographic phase transition (Figure S2). Such multiple spin-state conversions was already observed in warming mode for the $\left[\mathrm{Fe}(\mathrm{bpp})_{2}\right]\left[\mathrm{Ni}(\mathrm{mnt})_{2}\right]_{2} \cdot \mathrm{MeNO}_{2}$ compound (where $\mathrm{mnt}=$ maleonitriledithiolate) ${ }^{[27]}$ and in both cooling and warming modes for the $\left[\mathrm{Fe}(\mathrm{bppMe})_{2}\right]\left(\mathrm{BF}_{4}\right)_{2} \cdot \mathrm{xH}_{2} \mathrm{O}$ $(\text { bppMe }=2,6 \text {-bis (3-methylpyrazol-1-yl)pyridine })^{[28]}$.

$\left(T_{\text {LIESST }}=\mathrm{T}_{0}-0.3 \mathrm{~T}_{1 / 2}\right)^{[28]}$ which connects photomagnetism and thermal spin crossover and saying that higher the $T_{1 / 2}$ is found lower the $T_{\text {LIESST }}$ will be determined. $T_{1 / 2}$ is the thermal spin transition temperature, $T_{\text {LIESST }}$ is the light-induced excited spin state trapping temperature and $T_{0}$ is an empirical parameter determined equal to $150 \mathrm{~K}$ for meridional tridentate ligands ${ }^{[29]}$ Using such relation, a $T_{1 / 2}=340 \mathrm{~K}$ should lead to a $T_{\text {LIESST }}=48 \mathrm{~K}$ which is a value close to the experimental $\mathrm{T}_{\text {LIESST }}=55 \mathrm{~K}$.

$\left[\mathrm{Co}(\mathrm{L})_{2}\right]\left(\mathrm{BF}_{4}\right)_{2} \cdot 2 \mathrm{MeNO}_{2}\left(2 \cdot 2 \mathrm{MeNO}_{2}\right)$. The magnetic properties of 2.2 $\mathrm{MeNO}_{2}$ were probed measuring the magnetic susceptibility for an immobilized crystalline powder of the sample. The temperature dependence of the $\chi_{M} T$ product is depicted in the Figure S3. The room temperature value of $3.19 \mathrm{~cm}^{3} \mathrm{~K} \mathrm{~mol}^{-1}$ is larger than the expected spin-only value $\left(1.875 \mathrm{~cm}^{3} \mathrm{~K} \mathrm{~mol}^{-1}\right)$ for high-spin Coll ion. Nevertheless this experimental value is in agreement with the value range of 2.1-3.4 $\mathrm{cm}^{3} \mathrm{~K} \mathrm{~mol}^{-1}$ for an highly anisotropic Coll ions including a strong orbital angular momentum contribution. ${ }^{[29]}$ Upon cooling, the $\chi_{M} T(T)$ curve decreases monotonously to reach a value of $2.30 \mathrm{~cm}^{3} \mathrm{~K} \mathrm{~mol}^{-1}$ at $2 \mathrm{~K}$. The decreasing is mainly due to the magnetic anisotropy of the $\mathrm{Co}^{\text {Il }}$ with possible additional antiferromagnetic intermolecular interactions at low temperature.

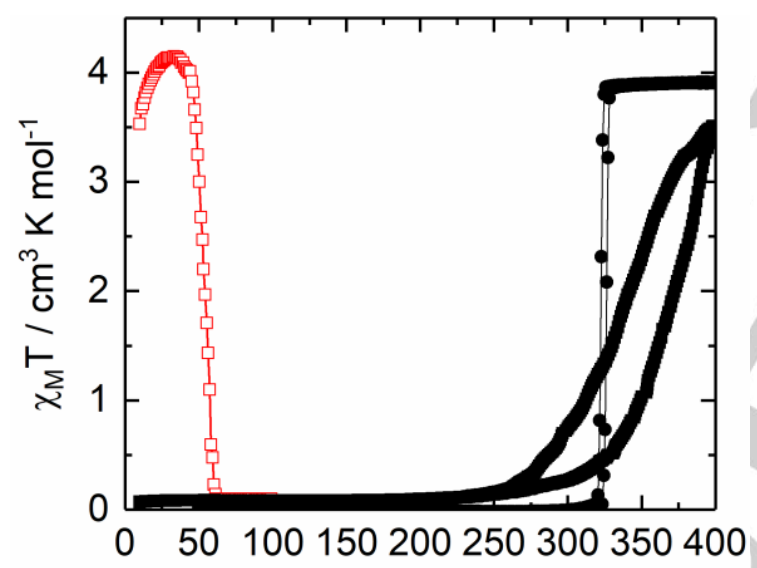

$\mathrm{T} / \mathrm{K}$

Figure 6. Thermal dependence of $\chi_{M} \mathrm{~T}$ for 1 (full circles), $1.4 \mathrm{MeNO}_{2}$ (full square) The thermal dependence of $\chi_{M} \mathrm{~T} 1.4 \mathrm{MeNO}_{2}$ after light irradiation $(660 \mathrm{~nm}, 5 \mathrm{~mW})$ is represented with red squares.

The red data plots of the Figure 6 shows the results of the irradiation at $660 \mathrm{~nm}$ in the tail of the absorption band which corresponds to the $d-d$ and/or Metal-to-Ligand Charge Transfer (MLCT) transitions of the LS state of $\mathbf{1 . 4 M e N O} \mathbf{M N}_{2}$ (Figure S3). After $5 \mathrm{~min}$ of light irradiation at $10 \mathrm{~K}$, almost all the LS fraction is converted in HS by population of the metastable ${ }^{5} \mathrm{~T}_{2 g}(\mathrm{Oh})$ state. Switching off the light leads to a population of the metastable ${ }^{5} \mathrm{~T}_{2 \mathrm{~g}}$ which persists up to $T_{\text {LIESST }}=55 \mathrm{~K}$ at a sweep rate of $0.3 \mathrm{~K} \mathrm{~min}^{-1}$. This value is lower than the $\mathrm{T}_{\text {LIESST }}$ measured under a light irradiation of $510 \mathrm{~nm}$ for the two solvatomorphs of the methylsubstituted-bpp analogues (87 and $112 \mathrm{~K}$ ). ${ }^{[9]}$ This experimental observation is perfectly in agreement with the linear relation
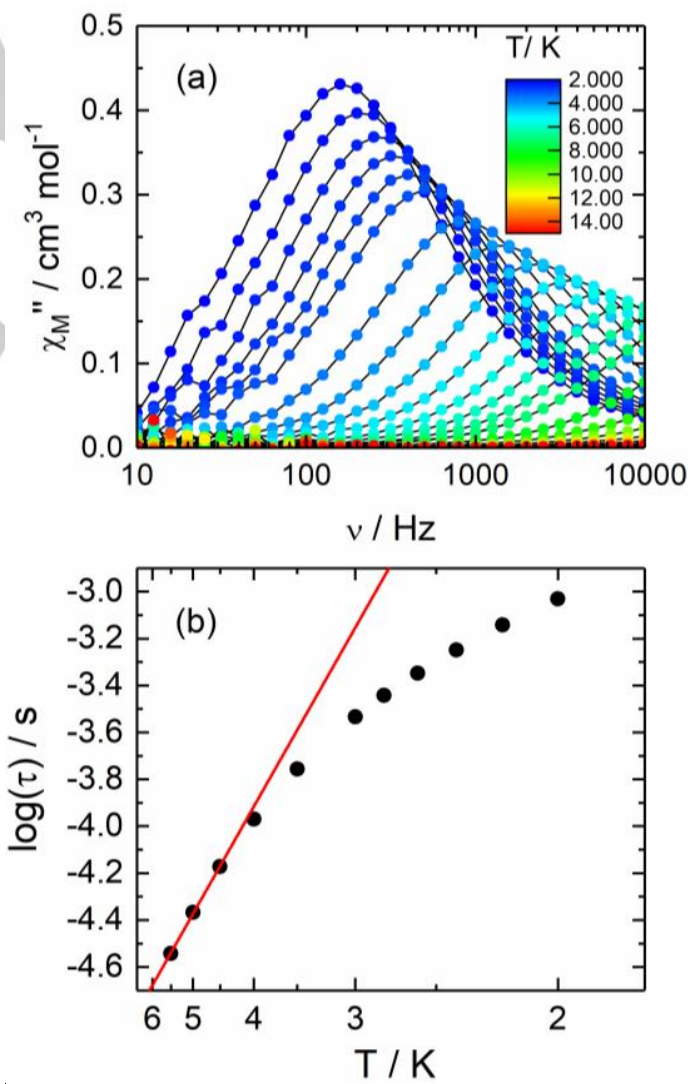

Figure 7. (a) Frequency dependence of the out-of-phase component of the magnetic susceptibility for $\mathbf{2} \cdot \mathbf{2} \mathbf{M e N O}_{2}$ between 2 and $14 \mathrm{~K}$ under an applied DC field of $1000 \mathrm{Oe}$. (b) Arrhenius plot of the thermal dependence of the relaxation time of the magnetization. The red line represents a fit for the high-temperature region. 
The magnetic field dependence of the magnetization at $2 \mathrm{~K}$ between 0 and $50 \mathrm{kOe}$ is depicted in inset of the Figure S4. At the maximum field value the magnetization takes the value of $2.50 \mu_{\mathrm{B}}$ but without reaching a saturation sign of significant magnetic anisotropy. Consequently the magnetic relaxation dynamics were probed by measuring the frequency-dependence ac susceptibility below $15 \mathrm{~K}$. No out-of-phase component of the magnetic susceptibility was detected under zero dc field. Nevertheless application of a moderated dc field provokes the appearance of an out-of-phase which is centred at $160 \mathrm{~Hz}$ at $2 \mathrm{~K}$ for the optimal dc field of 1000 Oe (Figure S5). Such cancelling of the tunnelling magnetic relaxation is very common for Co"-based SMM. The compound 2.2 $\mathrm{MeNO}_{2}$ displayed typical field-induced mononuclear SMM under an applied dc field of 1000 Oe (Figures $\mathrm{S} 6$ and $7 \mathrm{a})$. From the frequency dependence of the magnetic susceptibility is generated the Cole-Cole plots below $14 \mathrm{~K}$ (Figure S7). The values $(\alpha)$ and the distribution of relaxation time $(\tau)$ were extracted using a generalized Debye model (Table S1) ${ }^{[31]}$ while the energy barrier $\Delta$ was evaluated from the linear fit of the high temperature region of the Arrhenius plot (Orbach regime) (Figure $8 b)$. Using the following equation $\tau=\tau_{0} \exp \left(U_{\text {eff }} / k_{B} T\right)$, the best fit gives $U_{\text {eff }}=14.6(4) \mathrm{cm}^{-1}$ and $\tau_{0}=6.28(8) \times 10^{-7} \mathrm{~s}$. The $\alpha$ values range from 0.02 to 0.12 suggesting a narrow distribution of the relaxation time.

\section{Conclusions}

The association of the ligand 2,6-di(pyrazol-1-yl)-4(bromomethyl)pyridine (L) with the divalent metallic ion Fe(II) and $\mathrm{Co}$ (II) led to the formation of mononuclear complexes of formula $\left[\mathrm{M}(\mathrm{L})_{2}\right]\left(\mathrm{BF}_{4}\right)_{2} \cdot \mathrm{XMeNO}_{2}$. The $\mathrm{Fe}$ ll based compound crystallized in two solvatomorphs $\left[\mathrm{Fe}(\mathbf{L})_{2}\right]\left(\mathrm{BF}_{4}\right)_{2}(\mathbf{1})$ and $\left[\mathrm{Fe}(\mathbf{L})_{2}\right]\left(\mathrm{BF}_{4}\right)_{2} \cdot 4 \mathrm{MeNO}_{2}$ $\left(1.4 \mathrm{MeNO}_{2}\right.$ ). The LS Fell crystal structure of the unsolvated derivative highlighted a partial "terpyridine embrace" type crystal packing while the solvated derivative did not. As a consequence, both solvatomorphs displayed thermal Spin Crossover at high temperature $\left(T_{1 / 2}=320-340 \mathrm{~K}\right)$ nevertheless the one for 1 presented an abrupt spin transition with a straight hysteresis loop while $1.4 \mathrm{MeNO}_{2}$ presented a more gradual spin transition with the widest thermal hysteresis $(35 \mathrm{~K})$ for this type of complexes. In addition the spin transition in cooling mode operated in a six-step manner. Finally the $1.4 \mathrm{MeNO}_{2}$ solvatomorph is photo-active with an efficient LIESST effect under light irradiation at $530 \mathrm{~nm}$ and $\mathrm{T}_{\text {LIESST }}=55 \mathrm{~K}$. The $\left[\mathrm{Co}\left(\mathrm{L}_{2}\right]\left(\mathrm{BF}_{4}\right)_{2} \cdot 2 \mathrm{MeNO}_{2}\left(\mathbf{1} \cdot \mathbf{2} \mathrm{MeNO}_{2}\right)\right.$ complex did not show any spin transition but the dynamic magnetic properties highlighted a mononuclear SMM behaviour under an applied dc field of 1000 Oe with an effective energy barrier of $14.6(4) \mathrm{cm}^{-1}$ and a relaxation time of $6.28(8) \times 10^{-7} \mathrm{~s}$. Both Fell and $\mathrm{Co}^{\text {"l }}$ derivatives shown promising magnetic properties and they could be used as metallo-precursors for further functionalization thank the bromo-methyl groups.
Synthesis. General Procedures and Materials. The ligand 2.6di(pyrazol-1-yl)-4-bromomethyl)pyridine (L) ${ }^{[14]}$ was synthesized following previously reported methods. All other reagents were purchased from Acros, Alfa Aesar, Aldrich Co., Ltd. and used without further purification.

Synthesis of $\left[\mathrm{Fe}(\mathrm{L})_{2}\right]\left(\mathrm{BF}_{4}\right)_{2} \cdot \mathrm{xMeNO} \mathrm{Me}_{2}\left(\mathrm{x}=0\right.$ (1) and $\mathrm{x}=4\left(1.4 \mathrm{MeNO}_{2}\right)$. $50.6 \mathrm{mg}$ of $\mathrm{Fe}\left(\mathrm{BF}_{4}\right)_{2} \cdot 6 \mathrm{H}_{2} \mathrm{O}(0.15 \mathrm{mmol})$ and $91.2 \mathrm{mg}$ of $\mathrm{L}(0.30 \mathrm{mmol})$ were dissolved in $15 \mathrm{~mL}$ of $\mathrm{CH}_{3} \mathrm{NO}_{2}$ and heated to reflux for $3 \mathrm{~h}$ under argon atmosphere. After cooling to room temperature, the solution was stirred overnight and then concentrated to a volume of c.a. $7.5 \mathrm{~mL}$. The resulting brown solution was divided in 5 glass hemolysis tubes and slow diffusion of $\mathrm{Et}_{2} \mathrm{O}$ vapour led to the formation of brown plate $(\mathrm{x}=0)$ and prism $(\mathrm{x}=4)$ single crystals suitable for $X$-ray analysis. Yield: $73 \mathrm{mg}$ (about $54 \%$ based on single crystals). Anal. Calcd (\%) for C24H20F8FeN10Br2B2: C 34.36, H 2.39, N 16.71; found: C 34.39, H 2.44 N, 16.54. Anal. Calcd (\%) for C28H32F8FeN14O8Br2B2 C 31.05, H 2.96, N 18.11; found: C 31.09, H 3.07 N, 18.04. I.R. (KBr): 3128 (w), 3093 (w), 3022 (w), 2965 (w), 2918 (w) $1620(\mathrm{~s}), 1577(\mathrm{~s}), 1522(\mathrm{~m}), 1467(\mathrm{~s}), 1399(\mathrm{~s}), 1262(\mathrm{~m}), 1207(\mathrm{~m}), 1114$ (w), $1084(\mathrm{~m}), 1042(\mathrm{~s}), 958(\mathrm{~m}), 918(\mathrm{w}), 860(\mathrm{w}), 789(\mathrm{~m}), 764(\mathrm{~s}), 672$ $(w), 643(w), 606(w)$ and $566(w) \mathrm{cm}^{-1}$.

Synthesis of $\left[\mathrm{Co}(\mathrm{L})_{2}\right]\left(\mathrm{BF}_{4}\right)_{2} \cdot 2 \mathrm{MeNO}_{2}\left(2 \cdot 2 \mathrm{MeNO}_{2}\right)$. Similar experimental procedure than for the $\mathrm{Fe}^{\mathrm{ll}}$ derivatives was used except that $51.3 \mathrm{mg}$ of $\mathrm{Co}\left(\mathrm{BF}_{4}\right) \cdot 6 \mathrm{H}_{2} \mathrm{O}$ was employed instead of $\mathrm{Fe}\left(\mathrm{BF}_{4}\right)_{2} \cdot 6 \mathrm{H}_{2} \mathrm{O}$. The resulting yellow-brownish solution was divided in 5 glass hemolysis tubes and slow diffusion of $\mathrm{Et}_{2} \mathrm{O}$ vapour led to the formation of yellow board single crystals suitable for X-ray analysis. Yield: $85 \mathrm{mg}$ (about $59 \%$ based on single crystals). Anal. Calcd (\%) for C26H26F8CoN12O4Br2B2: C 34.42, H 1.68 N 4.15; found: C 34.69, H 1.74 N, 4.14. I.R. (KBr): 3130 (w), 3089 (w), $3063(w), 3039(w), 3009(w), 2915(w), 1638(s), 1580(s), 1525(m), 1471$ (s), $1404(\mathrm{~s}), 1339(\mathrm{~m}), 1310(\mathrm{~m}), 1285(\mathrm{~m}), 1174(\mathrm{~m}), 1114(\mathrm{w}), 1084(\mathrm{~m})$ $1042(\mathrm{~s}), 969(\mathrm{~m}), 915(\mathrm{w}), 860(\mathrm{w}), 770(\mathrm{~m}), 678(\mathrm{w}), 641(\mathrm{w}), 598(\mathrm{~m})$ $524(w)$ and $448(w) \mathrm{cm}^{-1}$.

X-ray diffraction. Single crystal of $1,1.4 \mathrm{MeNO}_{2}$ and $2.2 \mathrm{MeNO}_{2}$ were mounted on a APEXIII D8 VENTURE Bruker-AXS diffractometer for data collection (MoK $\alpha$ radiation source, $\lambda=0.71073 \AA$ ), from the Centre de Diffractométrie (CDIFX), Université de Rennes 1, France (Table 1). Structure was solved with a direct method using the SHELXT program ${ }^{[32}$ and refined with a full matrix least-squares method on F2 using the SHELXL-14/7 program ${ }^{[33]}$. Complete crystal structure results as a CIF file including bond lengths, angles, and atomic coordinates are deposited as Supporting Information.

Physical Measurements. The elementary analyses of the compounds were performed at the Centre Régional de Mesures Physiques de l'Ouest Rennes. Single crystals of $1,1.4 \mathrm{MeNO}_{2}$ and $2.2 \mathrm{MeNO}_{2}$ are manually selected and their cell parameters are checked before magnetic measurements. The dc magnetic susceptibility measurements were performed on grinded previously selected single crystal in Teflon tape with a Quantum Design MPMS-XL SQUID magnetometer between 2 and 300 $\mathrm{K}$ in applied magnetic field of $0.02 \mathrm{~T}$ in the temperature range $2-20 \mathrm{~K}, 0.2$ $\mathrm{T}$ in the temperature range $20-80 \mathrm{~K}$ and $1 \mathrm{~T}$ above $80 \mathrm{~K}$. These measurements were all corrected for the diamagnetic contribution of the Teflon tape and the intrinsic diamagnetism calculated with Pascal's constants.

\section{Acknowledgements}

\section{Experimental Section}


We acknowledge financial support from CNRS, Université de Rennes 1 and ERC Consolidator Grant MULTIPROSMM (Proj. no. 725184).

Keywords: Iron • Cobalt • dipyrazolylpyridine $\cdot$ Single-Molecule Magnet $\cdot$ Spin Crossover

[1] a) L. Bogani, W. Wernsdorfer, Nat. Mater. 2008, 7, 179-186; b) M. N. Leuenberger, D. Loss, Nature 2001, 410, 789-793; c) J. Lehmann, A Gaita-Arino, E. Coronado, D. Loss, J. Mater. Chem. 2009, 19, 1672 1677; d) O. Kahn, C. J. Martinez, Science 1998, 279, 44-48.

[2] a) R. Sessoli, D. Gatteschi, A. Caneschi, M. A. Novak, Nature 1993, 365, 141-143; b) G. Aromi, E. K. Brechin, in Single-Molecule Magnets and Related Phenomena, ed. R. Winpenny, 2006, p. 1-67.

[3] a) P. Gütlich, Y. Garcia, H. A. Goodwin, Chem. Soc. Rev. 2000, 29, 419427; b) A. Bousseksou, G. Molnar, L. Salmon, W. Nicolazzi, Chem. Soc Rev. 2011, 40, 3313-3335; c) M. C. Munoz, J. A. Real, Coord. Chem. Rev. 2011, 255, 2068-2093; d) G. Aromí, L. A. Barrios, O. Roubeau, P. Gamez, Coord. Chem. Rev. 2011, 255, 485-546; e) M. A. Halcrow, Chem. Soc. Rev. 2011, 40, 4119-4142; f) M. A. Halcrow Spin-Crossover Materials-Properties and Applications, ed. John Wiley \& Sons, Ltd.: New York, 2013.

[4] L. Cambi, A. Gagnasso, Atti. Accad. Naz. Lincei 1931, 13, 809-813.

[5] a) S. Decurtins, P. Gütlich, C. P. Köhler, H. Spiering, A. Hauser, Chem. Phys. Lett. 1984, 105, 1-4; b) P. Gütlich, A. Hauser, H. Spiering, Angew. Chem., Int. Ed. 1994, 33, 2024-2054; c) J.-F. Létard, J. Mater. Chem. 2006, 16, 2550-2559.

[6] a) Spin Crossover in Transition Metal Compounds I-III, Topics in Current Chemistry; Gütlich, P., Goodwin, H. A., Eds.; Springer-Verlag: Berlin, 2004; Vols. 233-235; b) A. Bousseksou, G. Molnár, L. Salmon, W. Nicolazzi, Chem. Soc. Rev. 2011, 40, 3313-3335; c) M. Cavallini, Phys. Chem. Chem. Phys. 2012, 14, 11867-11876; d) H. J. Shepherd, G. Molnar, W. Nicolazzi, L. Salmon, A. Bousseksou, Eur. J. Inorg. Chem. 2013, 653-661; e) M. C. Munoz, J. A. Real, Coord. Chem. Rev. 2011, 255, 2068-2093. f) J. Tao, R.-J. Wei, R.-B. Huang, L.-S. Zheng, Chem. Soc. Rev. 2012, 41, 703-737; g) Gütlich, P. Eur. J. Inorg. Chem. 2013, 581-591. h) P. Gütlich, A. B. Gaspar, Y. Garcia, Beilstein J. Org. Chem. 2013, 9, 342-391.

[7] L. J. Kershaw Cook, R. Kulmaczewski, S. A. Barrett, M. A. Halcrow, Inorg. Chem. Front. 2015, 2, 662-670.

[8] a) L. J. Kershaw Cook, R. Kulmaczewski, O. Cespedes, M. A. Halcrow, Chem. Eur. J. 2016, 22, 1789-1799; b) M. Fumanal, F. JiménezGravalos, J. Ribas-Arino, S. Vela, Inorg. Chem. 2017, 56, 4474-4483.

[9] L. J. Kershaw Cook, F. L. Thorp-Greenwood, T. P. Comyn, O. Cespedes, G. Chastanet, M. A. Halcrow, Inorg. Chem. 2015, 54, 63196330 .

[10] L. J. Kershaw Cook, R. Mohammed, G. Sherborne, T. D. Roberts, S. Alvarez, M. A. Halcrow, Coord. Chem. Rev. 2015, 289-290, 2-12.

[11] N. Ishikawa, M. Sugita, T. Ishikawa, S. Koshihara, Y. Kaizu, J. Am. Chem. Soc. 2003, 125, 8694-8695.

[12] R. Ishikawa, R. Miyamoto, H. Nojiri, B. K. Breedlove, M. Yamashita, Inorg. Chem. 2013, 52, 8300-8302 ; b) A. Grigoropoulous, M. Pissas, P. Rapatolis, V. Psycharis, P. Kyritsis, Y. Sanakis, Inorg. Chem. 2013, 52, 12869-12871 ; c) J. Vallejo, A. Pascual-Alvarez, J. Cano, I. Castro, M. Julve, F. Lloret, J. Krzystek, G. De Munno, D. Armentano, W. Wernsdorfer, R. Ruiz-Garcia, E. Pardo, Angew. Chem., Int. Ed. 2013, 52, 14075-14079.

[13] S. Mossin, B. L. Tran, D. Adhikari, M. Pink, F. W. Heinemann, J. Sutter, R. K. Szilagyi, K. Meyer, D. J. Mindiola, J. Am. Chem. Soc. 2012, 134, 13651-13661.

[14] a) W. H. Harman, T. D. Harris, D. E. Freedman, H. Fong, A. Chang, J. D. Rinehart, A. Ozarowski, M. T. Sougrati, F. Grandjean, G. J. Long, J. R. Long, J. Am. Chem. Soc. 2010, 132, 18115-18126; b) D. E. Freedman,
W. H. Harman, T. D. Harris, G. J. Long, C. J. Chang, J. R. Long, J. Am Chem. Soc. 2010, 132, 1224-1225; c) D. Weismann, Y. Sun, Y. Lan, G Wolmershauser, A. K. Powell, H. Sitzmann, Chem. Eur. J. 2011, 17, 4700-4704; d) P.-H. Lin, N. C. Smythe, S. J. Gorelsky, S. Maguire, N. J Henson, I. Korobkov, B. L. Scott, J. C. Gordon, R. T. Baker, M. Murugesu, J. Am. Chem. Soc. 2011, 133, 15806-15809.

[15] J. M. Zadrozny, D. J. Xiao, M. Atanasov, G. J. Long, F. Grandjean, F. Neese, J. R. Long, Nat. Chem. 2013, 5, 577-581.

[16] R. C. Poulten, M. J. Page, A. G. Algarra, J. J. Le Roy, I. Lopez, E. Carter, A. Llobet, S. A. Macgregor, M. F. Mahon, D. M. Murphy, M. Murugesu, M. K. Whittlesey, J. Am. Chem. Soc. 2013, 135, 13640-13643.

[17] J. Miklovič, D. Valigura, R. Boča, J. Titiš, Dalton Trans. 2015, 44, 12484 12487.

[18] Y.-S. Meng, Z. Mo, B.-W. Wang, Y.-Q., L. Deng, S. Gao, Chem. Sci. 2015, 6, 7156-7162

[18] a) A. Eichhofer, Y. Lan, V. Mereacre, T. Bodenstein, F. Weigend, Inorg Chem. 2014, 53, 1962-1974; b) J. M. Zadrozny, J. R. Long, J. Am. Chem. Soc. 2011, 133, 20732-20734; c) J. M. Zadrozny, J. Liu, N. A. Piro, C. J. Chang, S. Hill, J. R. Long, Chem. Commun. 2012, 48, 3927-3929; d) F. Yang, Q. Zhou, Y. Zhang, G. Zeng, G. Li, Z. Shi, B. Wang, S. Feng Chem. Commun. 2013, 49, 5289-5291; e) R. Boča, J. Miklovič, J. Titiš, Inorg. Chem. 2014, 53, 2367-2369; f) T. Jurca, A. Farghal, P.-H. Lin, I. Korobkov, M. Murugesu, D. S. Richeson, J. Am. Chem. Soc. 2011, 133, 15814-15817; g) F. Habib, O. R. Luca, V. Vieru, M. Shiddiq, I. Korobkov S. I. Gorelsky, M. K. Takase, L. F. Chibotaru, S. Hill, R. H. Crabtree, M. Murugesu, Angew. Chem., Int. Ed. 2013, 52, 11290-11293; h) J. Vallejo I. Castro, J. Ruiz-Garcia, J. Cano, M. Julve, F. Lloret, G. De Munno, W Wernsdorfer, E. Pardo, J. Am. Chem. Soc. 2012, 134, 15704-15707; i) E. Colacio, K. Ruiz, E. Ruiz, E. Cremades, J. Krzystek, S. Carretta, J. Cano, T. Guidi, W. Wernsdorfer, E. K. Brechin, Angew. Chem., Int. Ed. 2013, 52, 9130-9134; j) Y.-Y. Zhu, C. Cui, Y.-Q. Zhang, J.-H. Jia, X. Guo C. Gao, K. Qian, S.-D. Jiang, B.-W. Wang, Z.-M. Wang, S. Gao, Chem Sci. 2013, 4, 1802-1806; k) I. A. Gass, S. Tewary, A. Nafady, N. F. Chilton, C. J. Gartshore, M. Asadi, D. W. Lupton, B. Moubaraki, A. M. Bond, J. F. Boas, S.-X. Guo, G. Rajaraman, K. S. Murray, Inorg. Chem. 2013, 52, 7557-7572; I) R. Herchel, L. Váhovská, I. Potočňák, Z Trávníček, Inorg. Chem. 2014, 53, 5896-5898; m) T. J. Woods, M. F. Ballesteros-Rivas, S. Gomez-Coca, E. Ruiz, K. R. Dunbar, J. Am. Chem Soc. 2016, 138, 16407-16416.

[20] L. Chen, J. Wang, J.-M. Wei, W. Wernsdorfer, S.-T. Chen, Y.-Q. Zhang, Y. Song, Z.-L. Xue, J. Am. Chem. Soc. 2014, 136, 12213-11216.

[21] X.-N. Yao, J.-Z. Du, Y.-Q. Zhang, X.-B. Leng, M.-W. Yang, S.-D. Jiang Z.-X. Wang, Z.-W. Ouyang, L. Deng, B.-W. Wang, S. Gao, J. Am. Chem. Soc. 2017, 139, 373-380.

[22] C. Rajnak, J. Titiš, O. Fuhr, M. Ruben, R. Boča, Inorg. Chem. 2014, 53 , 8200-8202.

[23] T. Ayers, S. Scott, J. Goins, N. Caylor, D. Hathcock, S. J. Slattery, D. L. Jameson, Inorg. Chimica Acta 2000, 307, 7-12.

[24] a) M. Feng, F. Pointillart, B. Lefeuvre, V. Dorcet, S. Golhen, O. Cador, L. Ouahab, Inorg. Chem. 2015, 54, 4021-4028; b) S. Speed, M. Feng, G. Fernandez Garcia, F. Pointillart, B. Lefeuvre, F. Riobé, S. Golhen, B. Le Guennic, F. Totti, Y. Guyot, O. Cador, O. Maury, L. Ouahab, Inorg. Chem. Front. 2017, 4, 604-617.

[25] a) M. L. Scudder, H. A. Goodwin, I. G. Dance, New J. Chem. 1999, 23 695-705; b) R. Pritchard, C. A. Kilner, M. A. Halcrow, Chem. Commun 2007, 577-579; c) I. Dance, M. Scudder, CrystEngComm 2009, 11, 2233 2247.

[26] R. Mohammed, G. Chastanet, F. Tuna, T. L. Malkin, S. A. Barret, C. A Kilner, J.-F. Létard, M. A. Halcrow, Eur. J. Inorg. Chem. 2013, 819-831.

[27] M. Nihei, H. Tahira, N. Takahashi, Y. Otake, Y. Yamamura, K. Saito, H. Oshio, J. Am. Chem. Soc. 2010, 132, 3553-3560.

[28] V. A. Money, C. Carbonera, J. Elhaïk, M. A. Halcrow, J. A. K. Howard, J.-F. Létard, Chem. Eur. J. 2007, 13, 5503-5514.

[29] a) S. Marcén, L. Lecren, L. Capes, H. A. Goodwin, J.-F. Létard, Chem. Phys. Lett. 2002, 358, 87-95; b) V.A. Money, J. S. Costa, S. Marcén, G. 


\section{FULL PAPER}

Chastanet, J. Elhafflk, M.A. Halcrow, J. A. K. Howard, J.-F. Létard, Chem. Phys. Lett. 2004, 391, 273-277; c) C. Carbonera, J. S. Costa, V. A. Money, J. Elhafflk, J. A. K. Howard, M. A. Halcrow, J.-F. Létard, Dalton Trans. 2006, 3058-3066.

[30] F. E. Mabbs, D. J. Machin, Magnetism and Transition Metal Complexes: Dover Publications: Mineola, NY, 2008.

[31] K. S. Cole, R. H. Cole, J. Chem. Phys. 1941, 9, 341-351.

[32] G. M. Sheldrick, Acta Crystallogr. Sect. A 2015, 71, 3-8

[33] G. M. Sheldrick, Acta Crystallogr. Sect. C 2015, 71, 3-8. 


\section{FULL PAPER}

The three mononuclear complexes of $\mathrm{Fe}^{\prime \prime}$ and $\mathrm{Co}^{\prime \prime}$ involving the 2,6di(pyrazol-1-yl)-4-

(bromomethyl)pyridine (L) displayed thermal and photo-induced spin transition, and field-induced SingleMolecule Magnet behaviour respectively.

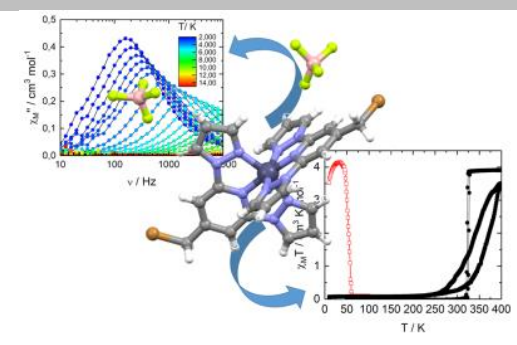

Co"l SMM and Fe" Spin CrossOver

Haiet Douib, Louis Cornet, Jessica Flores Gonzalez, Elzbieta Trzop, Vincent Dorcet, Abdelkrim Gouasmia, Lahcène Ouahab, Olivier Cador, ${ }^{*}$ Fabrice Pointillart,

Page No. - Page No.

Spin Crossover and Field-Induced Single-Molecule Magnet Behaviour in Metal(II)-Dipyrazolylpyridine Complexes 